\title{
Analysis of Food Security Program in Malika VDC of Dailekh District.
}

\author{
Krishna Prasad Gyawali ${ }^{1}$ and Chandra Bahadur Magar ${ }^{2}$
}

\begin{abstract}
This paper is an attempt to analyze the socio economic impact of food security program in the study area. Food security is widely defined as 'access by all people at all times to enough food for an active healthy life'. Food insecurity is, therefore, the inability of a household or individual to meet required consumption levels in the face of fluctuating production, prices and incomes. Food insecurity is one of the major problems of the rural community. Community peoples are suffered from more food vulnerability due to the low production \& having their traditional occupation as a way of livelihood. Their traditional occupation had faced different challenges due to modernization \& globalization. Communities have been affected by the low production, lack of improved agriculture technology, road accessibility, and market facility and have experienced of rapid socio-economic, cultural changes over generation. Their way of earning livelihood differ by the development activities \& these changes have been enumerated with case material from the survey.
\end{abstract}

Key words: Socio-economic, food security, access,community, livelihood

\section{Introduction}

Food security has been a consistent theme raised in specific contexts in a number of world conferences convened by the United Nations in the 1990s. The concept of food security as understood now has been evolved over the last quarter century. Food security concept has been considered at a number of levels: global, regional, national, household and individual. FAO (1983) had formulated that the basic concept of food security implied that 'all people at all times have both physical and economic access to the basic food that they need'. The World Bank (1986) has modified this formulation to indicate that food security is 'access by all people at all times to enough food for an active, healthy life.' This definition points out to four major components of food security, namely, availability, accessibility, utilization and vulnerability. Availability generally refers to production and physical availability of food in a given area. Access refers to economic access to food, i.e., the purchasing power of the people concerned, and utilization refers proper use of food commanded by a household and its members from their entitlement. Food sufficiency is the ability of a household to meet their demand of food through domestic production.

Agriculture is the backbone of Nepalese economy, and serves as the basis of livelihood and subsistence for the majority of its people. Despite its importance, the agricultural sector faces several challenges and limitations when it comes to meeting the demands of its growing population. The total population of Nepal is $264,94,504$, and population growth rate per annum is 1.35 (GoN,2014). Agriculture sector has been

1 Asst. Lecturer, Dept. of Economics and Rural Development, Saptagandaki Multiple Campus, Bharatpur

2 M.A., R.D., Student Researcher, Saptagandaki Multiple Campus, Bharatpur 
significantly contributing to the Nepalese economy. Agriculture occupies around one third of GDP while two third of the population is dependent on agriculture as a profession. Agriculture sector had contributed 32.12 percent of GDP in fiscal year 2014/15. Annual growth rate of agriculture is 1.14 percent (GoN,2016).

The Mid-West Region of Nepal is suffering from the food insecure situation. This region is characterized by poor access to markets, limited economic opportunities and minimal provision of basic government services, leading to low health and education indicators. Poverty rates are highest in the region where the population has limited access to paved roads, health and education facilities, and market centers. Lower castes represent the poorest segment of the population in the hills, followed by other Ethic castes. The mid hills and mountain ranges are still suffering from food deficits. The rough terrain, poor water and irrigation supply and lack of access to agriculture inputs and services have forced many people to leave their land barren, losing their livelihoods in the process.

Food security in Nepal depends on land productivity as managed by small holders who face challenges in productivity and sustainability, and the country is prone to natural disasters that can have serious consequences for agricultural production. The World Food Programme (WFP) of the United Nations conducted a Food Security and Vulnerability Analysis (FSVA) in 2005 in order to understand the food insecurity and vulnerability situation in Nepal. A total of 1676 households represented agro-ecological regions of Nepal (Terai, Hills, and Mountains) across all five Development Regions. The study revealed that approximately $27 \%$ of rural households are food insecure and have a very poor food consumption pattern. Chronic malnutrition and low weights are common; 49\% of children aged 0-59 months are underweight and $46 \%$ are stunted. Among the Far-Western and mid-Western Regions of the country contain the highest concentration of households with poor or very poor food consumption patterns (Subedi, 2007).

Nepalese agriculture cannot meet the growing food requirements of its exploding population. Rapidly increasing population which puts pressure on limited land resources causes low land productivity. Low production, distribution, poor access to food in remote areas, and low income are key factors causing food insecurity. Past agricultural efforts have not gone far enough. Research, extension, and capacity building programs should be pro-poor and women focused. The government must provide top priority to irrigation and road links in order to increase production, distribution, and access to food. Crop diversification, conservation agriculture, and rural income-generating activities should be the priority in rural areas.

\section{Study Area and Methods}

Malika VDC for the research study is one of the remote and under developed VDC among 55 VDCs in Dailekh district that is about $30 \mathrm{~km}$ far from the district headquarters at northern part. The geographical location of this VDC is slope and most of the settlements are scattered. According to the Census 2011, the total households of this VDC is 1061 and total population is 5564 where male is 2637 and female is 2927 . The absentee household is 292 in the VDC. The average household size of the VDC is 5.24 (GoN,2014). According to the VDC record, more than 85 percent of the population is engaged in subsistence agriculture and livestock rising. The rest 15 percent of the population is engaged either in government jobs, school teaching, overseas jobs, business and study. Since 
land is the major resource they exploit, most of it is used as either Khet or Bari or public land. Food grains like paddy, wheat and maize are cultivated in the Khet whereas maize, mustard, vegetable and beans are cultivated in the Bari as major crops. Most of the public land is either used for grazing or community forest from which the community people get fodder, firewood, grass etc. Almost all households have access to involvement in food security program supported by WFP and Oxfam which was implemented by different partner organizations due to the vulnerability caused by ongoing conflict, natural disaster, low productivity and income. The production status of this VDC is low due to the lack of irrigation facility, improved seed and technology support, affected by seasonal disaster, fertile soil erosion, land slide as well as conflict. Most of the households were displaced during the conflict period and after a long time they were replaced with the help of different humanitarian organization.

This study has drawn data and information from both primary and secondary sources. The primary data was collected by using different methods, such as household survey, field observation, focus group discussion and key informant interview. Out of 607 households, 121 households (20\% from each ward) were selected randomly. Most of the interviews were done with the family head of house as well as with the housewives and other family members who were available at that time.

\section{Conceptual Framework for Analyzing Food Security}

The conceptual framework developed from definitions, and the elements that constitute them are used in the present study. This framework addresses important concerns of UNDP and FAO in guiding their missions. If the world food summit definition is accepted, then the three major sequentially interlinked components of food security; food availability, food access and food utilization must be a central focus of the analysis. These three components are themselves determined, individually or jointly, by a number of factors. The broad conceptual framework adopted for the analysis of food security concerns is presented in Figure 1.

Figure:1. Conceptual Framework for Food Security Analysis

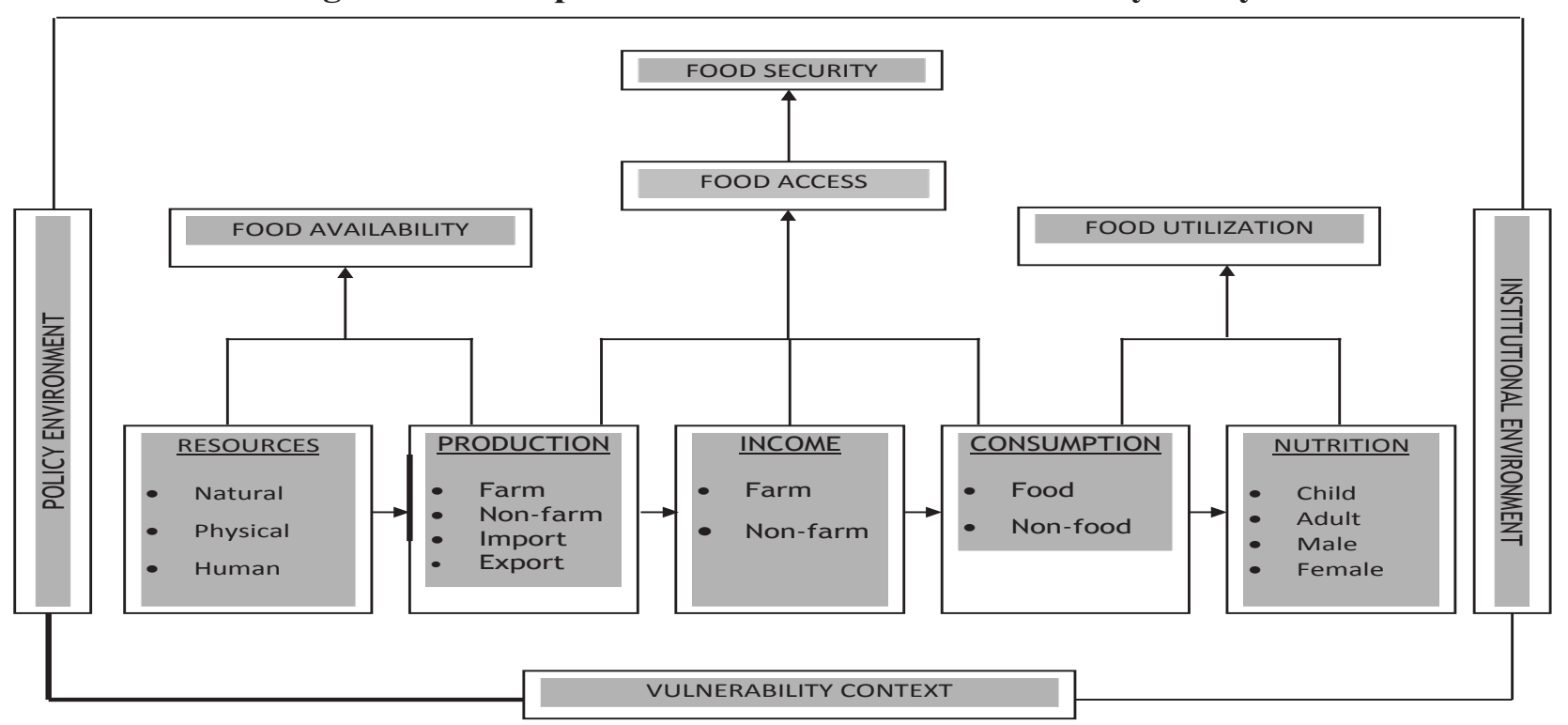

Source: Adopted from UNDP and FAO Report, 2008 
All of the factors that influence food availability, food access and food utilization and thereby the food security situation of households and individuals are affected by the policy and institutional environment under which they live, over which they have little control. The vulnerability context of households is influenced by time trends in variables like population growth, resources, technology, shocks resulting from factors like bad health, natural calamities, economic events and conflicts; and seasonality of prices, production, employment, etc., all of which eventually affect individual and household livelihood systems.

\section{Results and Discussion}

\section{Major Organizations of Food Security Program at Study Area}

The two main organizations involved in the study area to support the food security program are mentioned below.

\section{World Food Program (WFP)}

World Food Program is an agency of United Nations which had stated to works in Nepal before 40 years in of Nepal. It is a largest organization involved to fighting for hunger and its ultimate goal in Nepal is to break the cycle of poverty and hunger. The main focus of this organization is to:

- Prevent acute hunger and meet emergency food and nutrition needs,

- Empower hundreds of thousands of families through food- and cash-for-work to build assets that will improve long-term food security,

- Support the government and partners to develop and implement effective food security and nutrition strategies.

WFP had launched the Assistance for Vulnerable Populations Affected by Conflict, High Food Prices and Natural Disasters, Food Assistance to Refugees, Country Program (Vitamin Mishran for children, School Feeding/Girls Incentive Program, Maternal and Child Health Care) before starting period.

\section{a. Protracted Relief and Recovery Operations (PRRO) Program}

WFP had started Food Security Project - Protracted relief and recovery operations (PRRO) in the Mid-West hills and mountains in 2008 to provide food (from 2009, also cash) assistance to the most food insecure people who are suffering from the shocks of drought, high food prices and continued political instability. PRRO program is implementing food/cash for-asset schemes to create productive assets and to restore and rebuild livelihoods. Project had support through emergency operation addresses immediate food needs of Nepal's poor while enabling communities to create economic opportunities and productive assets to reduce chronic hunger and poverty.

Targeted people receive food and cash assistance in exchange for work to create vital assets like rural agriculture roads, trails, irrigations systems and other agriculture production creating activities that will contribute to longer-term food security. PRRO aims to create community level infrastructure like irrigation schemes, plantation work, and agro production related community facilities in study area. 


\section{b. Nepal Khaddya Surakxya Anugaman Pranali (NeKSAP)}

Nepal Khadhya Surakshya Anugaman Pranali(NeKSAP) is the comprehensive food security monitoring and analysis system in Nepal. Initiated by the United Nations World Food Programme (WFP) in 2002, NeKSAP is now jointly operated by the Ministry of Agricultural Development (MoAD) and WFP under the guidance of the National Planning Commission (NPC) and with support from the European Union. The NeKSAP decentralized food security analysis process uses 17 indicators representing four dimensions of food security: availability, access, utilization and stability. NeKSAP uses the Integrated Food Security Phase Classification (IPC) methodology to classify the severity of food insecurity into five phases. District Food Security Networks (DFSNs), established in 74 of the 75 districts of Nepal, are at the core of NeKSAP, comprising officials and representatives from district-based government agencies, development partners such as NGOs and UN agencies, as well as civil society. The DFSNs assess and monitor the food security situation in the respective districts using a standardized food security phase classification approach.

\section{Table:1. NeKSAP International Phase Classification (IPC)}

\begin{tabular}{|c|c|c|c|}
\hline Phase & $\begin{array}{c}\text { NeKSAP Phase } \\
\text { Names }\end{array}$ & $\begin{array}{c}\text { Equivalent } \\
\text { Phases IPC v2 }\end{array}$ & Description \\
\hline I & $\begin{array}{l}\text { Minimal Food } \\
\text { Insecure }\end{array}$ & Minimal & $\begin{array}{l}\text { Households with secure food and non-food needs without } \\
\text { shifting or changing livelihood strategies. These households are } \\
\text { capable of adjusting to small scale stresses caused by hazards, } \\
\text { disasters, shocks, epidemics and conflicts or violence by means } \\
\text { of existing social, natural and economic capital }\end{array}$ \\
\hline II & $\begin{array}{l}\text { Moderately Food } \\
\text { Insecure (or } \\
\text { Stressed }\end{array}$ & Stressed & $\begin{array}{l}\text { Households meet minimal food needs with traditional coping } \\
\text { strategies, but are unable to afford some essential non-food } \\
\text { expenditures without engaging in irreversible coping strategies }\end{array}$ \\
\hline III & $\begin{array}{l}\text { Highly Food } \\
\text { Insecure (or } \\
\text { Crisis) }\end{array}$ & Crisis & $\begin{array}{l}\text { Households experience food consumption gaps and high or } \\
\text { above usual acute malnutrition, or meet minimal food needs } \\
\text { only with accelerated depletion of livelihood assets - leading } \\
\text { to food consumption gaps. }\end{array}$ \\
\hline IV & $\begin{array}{l}\text { Severely Food } \\
\text { Insecure (or } \\
\text { Emergency) }\end{array}$ & Emergency & $\begin{array}{l}\text { Households unable to meet food and non-food needs without } \\
\text { losing livelihood assets. This induces very high acute } \\
\text { malnutrition leading to high morbidity, mortality and shortened } \\
\text { life expectancy. Probable high level of violence and movement } \\
\text { restriction due to conflict. Some immediate interventions and } \\
\text { assistance required. }\end{array}$ \\
\hline $\mathrm{V}$ & $\begin{array}{l}\text { Humanitarian } \\
\text { Em e rgency } \\
\text { (or Declared } \\
\text { Famine) }\end{array}$ & Famine & $\begin{array}{l}\text { Almost all households have an extreme lack of food and other } \\
\text { basic needs where starvation, destitution, irreversible loss of } \\
\text { capital resources and loss of lives are evident. Households of } \\
\text { the whole areas are challenged by acute shortage of food and } \\
\text { other basic needs - hazards, disasters, epidemics or destruction of } \\
\text { infrastructure, disturbances of services. Immediate humanitarian } \\
\text { assistance required. }\end{array}$ \\
\hline
\end{tabular}




\section{Oxfam Great Britain}

Oxfam Great Britain has been working in Nepal since the 1980s, addressing the poverty and injustice faced by women and other socially excluded groups through a variety of projects. Since the restoration of democracy in 1990 it has become easier for civil society to work in the new political environment, and its work in Nepal has been able to increase substantially. Public Health and Basic Livelihoods Support (PHABLeS) is one of the major programs of Oxfam in Nepal, which focuses on Public Health promotion and rural development. Under this PHABLeS program, Oxfam has assisted to implement the program through partner in Dailekh since 2005. Oxfam GB assisted to implement the food security improvement program in nine VDCs of Dailekh from 2010-2012 where study VDC is one.

\section{Food Availability Pattern before the Program Intervention}

Due to the low productivity of land/crops, unavailability of improved and high yielding varieties seed, poor utilization and unmanaged use of fertilizers, lack of irrigation facilities, lack of improved agriculture technology and technical support, people from study area where facing the problem of food deficiency form the beginning to program implementing period. Researchers tried to explore the pattern of food availability before the program period. This table shows the food availability pattern for the whole year from own production before implementation of the food security program in the study area.

\section{Table:2.Food Availability Pattern before the Project Intervention}

\begin{tabular}{|c|l|c|c|}
\hline \multirow{2}{*}{ S.N. } & \multirow{2}{*}{ Food Available Months } & \multicolumn{2}{|c|}{ No. of Respondent HHs } \\
\cline { 3 - 4 } & & No. of HHs & Percentage \\
\hline 1 & Up to 3 Months & 72 & 60 \\
\hline 2 & $3-6$ Months & 45 & 37 \\
\hline 3 & 6 - 9 Months & 4 & 3 \\
\hline 4 & 9 - 12 Months & 0 & 0 \\
\hline & Total & $\mathbf{1 2 1}$ & $\mathbf{1 0 0}$ \\
\hline
\end{tabular}

Sources: Field Survey, 2015

The study of food security program in Malika VDC indicated that $60 \%$ respondents were having access for up to 3 months, which is very poor scenario from the prospective of food security. Among total household $37 \%$ were having access for 3 to 6 months, only $3 \%$ HHs were having for 6-9 months and no household have access for 9 to 12 months food availability for a whole year from their own production. This data shows that majority of the households were under vulnerability. Community people needs additional support from the respected stakeholders. It clearly shows that the agriculture pattern is undeveloped, traditional and less productivity in the study area. According to the above data, study area needs improvement in agriculture sector by giving productive training, inputs and improved technologies of agriculture. 


\section{Major Intervention of the Program}

The food security status of study area is basically determined by their awareness level on agriculture, community assets, technology transfer system and logistic factors. The complexity of the food security problem can be simplified by focusing on three distinct but interrelated dimensions: aggregate food availability, household food access, and individual food utilization. Vulnerability is a forward-looking concept for assessing community and household exposure and sensitivity to future shocks. Ultimately, it was found that the vulnerability of a household or community depended on its ability to cope with exposure to the risks associated with shocks such as drought, flood, crop blight or infestation, economic fluctuation, low level of knowledge, lacking of proper infrastructure facilities and technologies, and conflict. The people in the study areas were facing these problems before the program intervention. After the implementation of the program, sectorial intervention was made to enhance the capacity of the food defecated household and also community people. The upgraded ability support to manage these risks determined largely by the characteristics of a household or community, particularly community asset base and the livelihood and food security strategies it pursues. The determinants of applying coping capacity include the levels of a household's natural, physical, economic, human, social and political assets, the levels of its production, income and consumption, and its ability to diversify its income sources and consumption to mitigate the effects of the risks it may face at any moment. After implementation of the program, applied major interventions through food security program was as given below.

Table:3. Major Intervention Sector of Food Security Program

\begin{tabular}{|c|c|c|}
\hline S.N. & Major Intervening Sector & Sub-Sectors/Activities \\
\hline 1. & Awareness Rising & $\begin{array}{l}\text { - Participatory Learning Center (PLC) } \\
\text { - Group Discussion } \\
\text { - Orientation } \\
\text { - } \text { Training } \\
\text { - Demonstration } \\
\text { - } \text { Cross Visit } \\
\text { - Practical Field Exercise }\end{array}$ \\
\hline 2. & Community Assets Creation & $\begin{array}{l}\text { - Rural Agriculture Road Construction } \\
\text { - Irrigation Cannel Construction } \\
\text { - } \text { Cement/Plastic Pond Construction } \\
\text { - Maintenance and Rehabilitation of Irrigation Canal } \\
\text { - } \text { River Bank Protection } \\
\text { - } \text { Terrace Improvement } \\
\text { - Nursery Installation } \\
\text { - Poly Houses Construction } \\
\text { - Improved Compost Pit Making } \\
- \text { Plantation } \\
- \text { Community Seed-bank Establishment } \\
- \text { Agriculture Group and Cooperative Formation and Registration } \\
- \text { Construction of PLC Building } \\
- \text { Supporting Access to Land for the Poor (Leasehold land) }\end{array}$ \\
\hline
\end{tabular}




\begin{tabular}{|c|c|c|}
\hline 3. & Technology Transfer & $\begin{array}{ll}\text { - } & \text { Improved Seed Support (Cereal \& vegetables) } \\
\text { - } & \text { Instrument Support } \\
\text { - } & \text { Pesticide Support } \\
\text { - } & \text { Improve Goat Support } \\
\text { - } & \text { Technical Support } \\
\text { - } & \text { Linkage Development with Stakeholders. }\end{array}$ \\
\hline 4. & Logistic Support & $\begin{array}{l}\text { - Food (Rice and Pulse) Support. } \\
\text { - Cash Support. }\end{array}$ \\
\hline
\end{tabular}

\section{Impact of the Food Security Program}

The effectiveness of the food security program in the study areas has been analyzed in terms of intervention and allocation of the service sectors comprising awareness raising, creation of community assets, technology transfer and logistic support. Program has invested on the above mentioned sectors to increase production and income of beneficiary HHs. It was found that changes were happened and the level of awareness was raised. Infrastructure facilities were developed at community level, transformation on agriculture technology was undertaken and adopted by the HHs and community people, short term logistic support was made to the community people behind the benefits of daily wages from the program activity which help for the short term food security. The role of improved technology in alleviating food deficiency was found greatest in a community where agriculture is absorbing by majority of population on land resources. Irrigation facility, improved seeds, fertilizers and other inputs and improved farm machinery were undertaken from modern agricultural technology. It was found that it helped to determine the level of agricultural productivity, which in turn affects poverty and food security, particularly in study area where agriculture is applying as a main source of livelihoods by the community people. From the field survey data, key informant response, direct observation and case studies the major effectiveness of the program intervention were as follows.

\subsection{Farmed Crops to Increase their Production and Income}

In many households, respondents have applied different improved varieties of corps which crops having high yielding performance and support to generate high income. Some of the respondents were farming offseasonal crops and earning additional income. To enhance the production and income of the respondents, other different line agencies provided technical/physical support to the community people. Respondents were adopting traditional seeds and farming system before the program implementation period. After intervention of the program, most of the farmers have changed their farming system and seed selecting pattern for the farming. The overall effects of irrigation schemes are, an increase in cropping intensity (are cultivating more crops in the same field which was never possible before irrigation support) changes in cropping pattern and increase in production. With the support of micro irrigation schemes some changes in cropping pattern has been observed which is as given below;

i. Paddy-fellow-Paddy has been replaced by Paddy-wheat-paddy

ii. Maize- wheat-maize has been replaced by Maize-bean-off season vegetable-maize

iii. Maize-mustard-maize has been replaced by maize + bean-potato-off season vegetable-Maize

iv. Maize-wheat-maize has been replaced by Maize-potato-potato-Maize. 
The farmers have various options that he/she can choose the best one from economic and soil fertility maintenance point of view. In addition to the above stated benefits, vegetable consumption in their daily diet has been found to increase as the trend of kitchen gardening has been scaled up significantly. Food Security Program supported and certified seeds of major crops to increase the production and income of the community people through program and they are:

- Paddy - Radha 4, Khumal -4, Hardinath, Loktantra, Bindesory etc.

- Maize - Deuti, Manakamana-1, Arun, Posilo, Shitala etc.

- Wheat - Annapurna -1 \& 3, WK-1204., Gautam, Danfe

- Cash Crops - Ginger, Yam, Pindalu, potato, Gram etc.

- High Value and fresh vegetable crops - Tomato, Cauliflower, Cabbage, Cucumber, Radish, Pea, Beans etc.

With the introduction of improved varieties of above stated crops combining technology, irrigation and market, beneficiaries have been able to enhance their food security by additional two- three months. From productivity increment point of view, beneficiaries have reported that they have been able to increase production by at least $25 \%-60 \%$ compared to the yield of traditional crop cultivation practices from their field before the intervention.

\subsection{Seed Using Pattern}

Although efforts to improved agriculture through food security program intervention, majority of the respondents and households have access to improved crops varieties/seed of paddy, maize and wheat distributed by program and existing partner organization, it was found that, household covered by improved seeds in a year depend only on the amount of improved seed distributed by formal sources, because there is also farmer-to-farmer spread. Thus actual coverage of crop households by improved seeds in a particular year is increasing.

However, it is observed that farmers start to replace traditional and low yielding varieties seeds as regularly as they should for optimal results for improved high yielding seeds. For the verification of the seed using pattern, researcher had designed the options for used types of seeds including foundation, certified -1, certified - 2, certified - 3 and own households seed. The following data shows the seed using pattern of the respondents.

\section{Table:4. Types of Seed Using Pattern by Sampled HHs}

\begin{tabular}{|c|l|c|c|}
\hline \multirow{2}{*}{ S.N. } & \multicolumn{2}{|}{ Options of Seed Used } & \multicolumn{2}{|c|}{ No of sample HHs } \\
\cline { 3 - 4 } & & No. of HHs & $\%$ \\
\hline 1 & Foundation Seed & 0 & 0 \\
\hline 2 & Certified - 1 and Own HHs & 6 & 5 \\
\hline 3 & Certified - 2 and Own HHs & 39 & 32 \\
\hline 4 & Certified - 3 and Own HHs & 57 & 47 \\
\hline 5 & Only Own HHs & 19 & 16 \\
\hline & Total & $\mathbf{1 2 1}$ & $\mathbf{1 0 0}$ \\
\hline
\end{tabular}

Source : Field Survey, 2015 
Table 4 indicates that adoption of improved seeds has increased during the program intervention period compared to before. The reasons are clear that the production and productivity of improved seed is higher than traditional seeds. It was found that there is still no access to foundation seed. It is also impossible and not applicable for the farmer's level. Foundation seed is specially applied by seed production center or research center. So, it can be said that farmer had no access on foundation seed. Certified seed is also a second generation seed of foundation seed. Only 5\% households have access on certified -1 and their self-stored improved seed. Majority of the household have access on certified -2 , certified $-3 \mathrm{~S}$ and their self-stored seeds. Among them 32\% households used certified - 2 and self-stored improved seed, 47\% households used certified - 3 and self-stored seed. $16 \%$ of them had no access to improved seed. They are using their self-produced traditional seeds. This figure shows that it is also necessary to bring awareness among community people about the improved seeds and need to make proper access to improved high yielding seeds. This can be considered as main tools to improve of food security.

\subsection{Sources of Seed Use}

The sources of seed are the basic components of the production. The analysis of the used seed sources by the respondents is one of the essential parts of this research work. So, it plays an important role in the analysis of food availability status of household. Similarly, in this study researchers have designed his household survey form and checklist to find out the seed source information. The following table shows the total number and percentage of household mentioning seed sources.

Table :5. Sources of Seed Use

\begin{tabular}{|c|l|c|c|}
\hline \multirow{2}{*}{ S.No } & \multirow{2}{*}{ Sources of Seeds } & \multicolumn{2}{c|}{ No. of sample respondents } \\
\cline { 3 - 4 } & & No. of HHs & \% \\
\hline 1 & DADO + Own HHs & 19 & 16 \\
\hline 2 & Agro-vet + Own HHs & 22 & 18 \\
\hline 3 & NARC + Own HHs & 24 & 20 \\
\hline 4 & Neighbours + Own HHs & 39 & 32 \\
\hline 5 & Only Own HHs & 17 & 14 \\
\hline & Total & $\mathbf{1 2 1}$ & $\mathbf{1 0 0}$ \\
\hline
\end{tabular}

Source: Field Survey, 2015

Table 5 indicates that selection of the seed sources during the program intervention period compared to before. It was found that there is no habit of using improved seed and no selection options for responsible source of seed due to the lack of awareness and additional technical support. After the intervention through different sector of the food security program the rate of using selection source options has been increased. Still farmers were using multiple options. Out of total sample population 16\% uses DADO and self-stored, 18\% used Agro-vet and self-stored, 20\% used NARC and self-stored, 32\% used from neighbor and selfstored and $14 \%$ used own production self-stored seeds. This figure shows that it is also necessary to aware people about the sources of seeds and the benefits behind selection of sources. 


\subsection{Production and Income Pattern of the Study Area}

Good quality seeds in sufficient quantities are essential for good harvests. Researcher found that before project intervention poor farmers in the study area have been using the same seeds for generations after generation due to remoteness, unavailability of improved high yielding seeds and lacks of know-how about the quality of these seeds. Understanding these problem, food security program had trained to the farmers in new farming techniques, distributing improved high yielding seeds, and seed storage bins. Community Seed bank was established constructing a building in the VDC that helped farmers to manage and store improved seeds from season to season, enabling them to grow larger crops even in the face of climate variation. Most of the households select the best seed stock for next year. The result of this practice shows the status of the production and income on annual basis of household which has slightly increased. Most of the respondents are cultivating food and cash crops like; paddy, maize, wheat, millet and barley and off seasons fresh vegetables as high value crops. Micro irrigation system has increased cropping intensity and brought changes in cropping pattern. It has provided an option for vulnerable communities to select the most economically beneficial and high profit making cropping pattern paying due attention to sustainable soil management too. The combined effects of activities on agriculture and agricultural inputs such as micro-irrigation system, improved seed distribution, seed multiplication, establishment of seed bank and improved farming system resulted in up to 50 percent increase in production as well as crop diversification. As a result, average production and income status of the respondent households increased as compared to previous year as shown the table below:

Table:6. Production Increment Status Compared to before Intervention of Sampled HHs

\begin{tabular}{|c|l|c|}
\hline S.N. & \multicolumn{1}{|c|}{ Main Crops } & Production Increment Percentage \\
\hline 1 & Paddy & 25 \\
\hline 2 & Maize & 50 \\
\hline 3 & Wheat & 30 \\
\hline 4 & Cash Crops/ vegetables & 30 \\
\hline
\end{tabular}

Source: Field Survey, 2015

Table 6 shows that the production status compared with previous is increased due to the access on improved seed, technology and irrigation facility. The data shows that $25 \%$ increment was found in paddy due to the selection of improved high yielding capacities seeds. $50 \%$ found in maize, $30 \%$ found in wheat and $30 \%$ is found in cash crops like; vegetable farming. This data shows the effectiveness of the food security program.

\section{Comparative Analysis of Food Availability (Before and After Program Intervention)}

After intervention through the food security program, changes are seen at household food production and income status was found increased, due to the raised knowledge in improved farming system and application of the gained knowledge, proper utilization of community assets, application of the improved technology as well as support of logistic. Similarly, lease holding farmers have taken 2-3 crops, which ultimately has 
contributed to support their additional food security by 3-4 months depending on the family size. The status of changing pattern on food availability before and after the project intervention is comparatively analyzed in the table below.

Table:7. Changed Food Availability Pattern before and after the Program Intervention

\begin{tabular}{|c|c|c|c|}
\hline \multirow{2}{*}{ S.N. } & \multirow{2}{*}{ Available Months } & \multicolumn{2}{|c|}{ Increment Status (in \%) } \\
\cline { 2 - 4 } & & Before & After \\
\hline 1 & Up to 3 Months & 60 & 35 \\
\hline 2 & $3-6$ Months & 37 & 47 \\
\hline 3 & $6-9$ Months & 3 & 15 \\
\hline 4 & $9-12$ Months & 0 & 3 \\
\hline \multicolumn{2}{r}{ Total } & $\mathbf{1 0 0}$ & $\mathbf{1 0 0}$ \\
\hline
\end{tabular}

Source: Field Survey, 2015

Table 7 shows the level of food availability is comparatively increased than before. The 3-6 month HHs was $37 \%$ before but later it was increased to $47 \%$ that was shifted from up to 3 month HHS. The percentage was found decreased from 60 to 35 from up to 3 month HHs. Same as food availability level of remaining HHs is found changed due to the effectiveness of food security intervention and the status of the household's food security is increased.

\section{Conclusion}

Agricultural production was very low due to recurrent problems of natural calamities, lack of adequate support services and use of traditional farm technologies. Consequently, majority of the households can produce enough food to cover their household's needs for not more than one quarter of the year. The households facing food deficiency adopt combination of different coping strategies like changing consumption behavior, working as casual labor, migrating out of the district or country, collection of wild foods, looking for the 'food for work' opportunities, sale of small livestock and poultry and so on. Seasonal migration to India in search of labor jobs was found to be one of the most prevalent forms of coping strategies adopted by the food insecure households. Rural households face number of risk factors with respect to their livelihoods. Most of the households were facing food scarcity before the program intervention. The problem of food stuff in study area arises due to various reasons such as, traditional farming and local seed, low level knowledge on high yielding improved seeds, unproductive size of land holding, low productivity, lack of agricultural credit, lack of market facilities, insufficient irrigation facility, poor access with stakeholders, poor awareness and other basic infrastructure etc. After the implementation of program, intervention was made according to the demand and the latest scenario of the community. Program activities were accomplished as per level of the household food security status. It was found that through awareness sector, community assets creation, technology transfer and short term logistic support has made to enhance the food availability through high production and income of the community people. The main abstracting part of production and income were 
lacking of proper knowledge on improved agriculture, poor community assets, application of traditional agriculture technology and unavailability of proper logistic at local level. During program implementation period, there were many constraints raised. Even though kind collaboration among community people, program and donor staffs and local social workers played the role to increase their active participation and reduce the conflict. It can proud say that lessons were learnt from the constraints. Constraints were the directors for coming days.

\section{References}

DDC (2067 BS). District Development Plan. Dailekh: District Development Committee.

DDC (2067 BS). Poverty Analysis Report. Dailekh :District Development Committee.

DDC (2013). District Profile of Dailekh. Dailekh: District Development Committee.

GoN (2014). National Population and housing census 2011. Kathmandu: Government of Nepal, National Planning Commission Secretariat, Central Bureau of Statistics.

GoN (2014). Population Monograph of Nepal Volume -I (Population Dynamics).Kathmandu: Government of Nepal, National Planning Commission Secretariat ,Central Bureau of Statistics

GoN (2016). Economy Survey. Kathmandu: Government of Nepal, Ministry of Finance .

GoN (2013).Thirteen Plan Approach Paper(FY2013/14-2015/16). Kathmandu: National Planning Commission.

MoHP (2011). Nepal Population Report. Kathmandu: Ministry of Health and Population.

NPC (2013). Nepal Thematic Report on Food Security and Nutrition. Kathmandu: National Planning Commission

Oxfam (2011). Final Narrative Report. Dailekh: Oxfam Field Office. 